\title{
TEKNIK PENGGAMBARAN AKTOR TERKAIT PERUNDUNGAN PASANGAN GAY THAILAND DI KORAN DIGITAL INDONESIA
}

\section{ACTORS REPRESENTATION TECHNIQUE RELATED TO THAI GAY COUPLES BULLYING IN INDONESIAN DIGITAL NEWSPAPERS}

\author{
Tiara Vidya Amalia ${ }^{1 *}$, Dadang S. Anshori ${ }^{2}$, Jatmika Nurhadi ${ }^{3}$ \\ Bahasa dan Sastra Indonesia, Universitas Pendidikan Indonesia, Indonesia 1,2,3 \\ $\underline{\text { tiaravidyaamalia@upi.edu }}^{1}$, dadanganshori@upi.edu ${ }^{2}$, jatmikanurhadi@upi.edu ${ }^{3}$ \\ *penulis korespondensi
}

\begin{tabular}{ll}
\hline Info Artikel & ABSTRAK \\
\hline Sejarah artikel: & Media sudah semakin mudah membuat dan menyebarkan berita karena \\
Diterima: & kemajuan teknologi. Penelitian ini bertujuan untuk mengetahui ada atau \\
17 Mei 2021 & tidaknya teknik yang digunakan oleh 5 koran digital Indonesia dalam \\
Direvisi: & mengeluarkan dan menggambarkan aktor atau peristiwa terkait pemberitaan \\
19 Juni 2021 & perundungan pasangan gay Thailand oleh netizen Indonesia dan \\
Disetujui: & memaparkan teknik apa saja yang digunakan oleh 5 koran digital Indonesia \\
3 Juli 2021 & itu. Metode yang digunakan adalah deskriptif kualitatif dan menggunakan \\
& teori analisis wacana kritis model Theo van Leeuwen. Penelitian ini \\
Kata kunci: & menemukan teknik eksklusi berupa pasivasi 4 data dan nominasi 2 data, \\
analisis wacama kritis, & serta teknik inklusi berupa diferensiasi-indifernsiasi 1 data, objektivitas- \\
Theo van Leeuwen, & abstraksi 4 data, nominasi-kategorisasi 2 data, nominasi-identifikasi 1 data, \\
eksklusi, inklusi & determinasi-indeterminasi 3 data, asimilasi-individualisasi 3 data dan \\
& asosiasi-disosiasi 1 data.
\end{tabular}

\begin{tabular}{ll}
\hline Article Info & ABSTRACT \\
\hline Article history: & The media has become easier to create and spread news because of \\
Received: & technological advances. This research aims to determine whether or not \\
17 May 2021 & there are techniques used by 5 Indonesian digital newspapers are available \\
Revised: & in issuing and describing actors or events related to the news of Thai gay \\
19 June 2021 & couples bullying by Indonesian netizens and to explain what techniques are \\
Accepted: & used by the 5 Indonesian digital newspapers. The method used is descriptive \\
3 July 2021 & qualitative and uses critical discourse analysis theory by Theo van \\
& Leeuwen's model. This study found exclusion techniques in the form of 4 \\
Keyword: & data passivation and 2 data nominations, as well as inclusion techniques in \\
critical discourse & the form of 1 data differentiation-indifferentiation, 4 data objectivity- \\
analysis, Theo van & abstraction, 2 data nominations-categorization, 1 data nomination- \\
Leeuwen, exclusion, & identification, 3 data determination-indertermination, 3 data assimilation- \\
inclusion & individualization and 1 data association-dissociation.
\end{tabular}

Copyright (C) 2021, Stilistika: Jurnal Pendidikan Bahasa dan Sastra DOI: http://dx.doi.org/10.30651/st.v14i2.8237

\section{PENDAHULUAN}

Penelitian ini mengkaji teknik yang digunakan koran-koran digital Indonesia dalam memberitakan peristiwa perundungan yang dilakukan netizen Indonesia terhadap pasangan gay Thailand. Hal tersebut perlu dikaji karena teknologi sudah semakin maju, media semakin mudah untuk membuat dan menyebarkan pemberitaan- 
pemberitaan yang sedang hangat diperbincangan oleh masayarakat melalui koran-koran digital dan masyarakat pun dengan mudah mengakses dan membaca berita tersebut. Berbagai teknik dilakukan oleh suatu media dalam menuliskan pemberitaan. Bisa untuk menghilangkan aktor dalam suatu berita atau bisa juga cara menggambarkan aktor dalam suatu berita. Selain itu, Indonesia dengan Thailand tentu saja memiliki budaya, suku, agama, dan ras yang berbedabeda. Bagi kebanyakan warga Indonesia adanya pasangan gay adalah hal yang susah untuk diterima di masyarakat dan melanggar agama terutama Islam. Akan tetapi, bagi warga Thailand adanya pasangan gay adalah hal yang lumrah. Sehingga, ketika pasangan gay tersebut memposting pernikahannya di Facebook, lalu warga Indonesia melihat postingan tersebut, maka mereka akan bereaksi karena perbedaan budaya tersebut.

Suatu media atau koran ketika menyampaikan, menginfromasikan, atau menyebarkan sebuah berita pasti menggunakan bahasa yang menurut Soeparno (2013) memiliki berbagai perwujudan seperti bahasa lisan, bahasa tulis, dsb. Bahasa tersebut digunakan suatu media sebagai alat komunikasi kepada para pembacanya (bahasa tulis) dan para pendengarnya (bahasa lisan). Hal tersebut sejalan dengan pengertian bahasa menurut Kridalaksana (2011) yaitu sistem lambang bunyi yang digunakan oleh masyarakat untuk berinteraksi dan sebagai alat komunikasi. Perwujudan dari bahasa tulis itu sendiri bisa ditemukan salah satunya pada koran-koran digital. Nantinya, koran tersebut akan disusun dengan satuan-satuan bahasa yang pada akhirnya akan membentuk satuan bahasa tertinggi yaitu wacana. Hal tersebut sejalan dengan pengertian wacana menurut KBBI yaitu satuan bahasa terlengkap atau tertinggi yang dibuat dalam bentuk karangan atau laporan utuh. Di lain pihak, wacana diartikan sebagai kesatuan makna yang utuh karena antarbagiannya memiliki hubungan yang padu (Kushartanti et al., 2009). Chaer (2012) menggambarkan bahwa satuan bahasa itu terdiri dari satuan yang terkecil hingga satuan yang lebih besar yaitu dari fonem ke morfem, lalu ke kata, ke frase, ke klausa, ke kalimat, dan terakhir wacana.

Semakin majunya teknologi, semakin mudah pula suatu media menyebarkan wacana yang telah dibuat, serta semakin banyak pula masyarakat yang menggunakan dan mengakses internet. Hal tersebut sejalan dengan laporan digital Kemp (2021) yang menunjukkan bahwa pengguna internet di seluruh dunia adalah 4,66 milyar dan di Indonesia sendiri adalah 202,6 juta pengguna. Tak jarang, masyarakat menggunakan internet itu untuk sesuatu yang tidak baik, seperti menipu, melecehkan, bahkan merundung. Seperti yang dilakukan oleh sejumlah warganet Indonesia di media sosial Facebook pada pertengahan April 2021 lalu, yaitu merundung pasangan gay Thailand yang baru saja menikah pada 3 April 2021. Kasus perundungan itu akhirnya viral, melihat bahwa media sosial Facebook adalah media sosial yang berada diurutan empat sebagai media sosial yang banyak digunakan oleh pengguna internet di Indonesia dengan persentase 85,5\% (Kemp, 2021). Jadi, tidak heran jika kasus tersebut banyak diberitakan oleh media-media daring atau koran digital Indonesia, seperti detik.com, kompas.com, brito.id, suara.com, makassar.terkini.id, dan 
masih banyak media lainnya yang memberitakan kasus perundungan tersebut.

Dengan demikian, permasalahan yang muncul berdasarkan latar belakang di atas adalah (1) adakah teknik yang digunakan koran digital untuk menggambarkan atau menyembunyikan peristiwa atau aktor terkait wacana pemberitaan perundungan terhadap pasangan gay Thailand? (2) bagaimana teknik eksklusi digunakan koran digital untuk mengeluarkan aktor atau peristiwa terkait wacana pemberitaan perundungan terhadap pasangan gay Thailand? dan (3) bagaimana teknik inklusi digunakan koran digital untuk menggambarkan aktor atau peristiwa terkait wacana pemberitaan perundungan terhadap pasangan gay Thailand?

Untuk mengetahui wacana yang dibuat oleh koran digital atau media online dalam menyampaikan, menyebarkan, dan menginformasikan sebuah berita, perlu yang namanya analisis wacana kritis atau critical discourse analysis. Analisis wacana kritis ini digunakan untuk membongkar maksud dan tujuan dari wacana yang telah dibuat oleh masing-masing koran atau media. Pertanyaan-pertanyaan di atas dapat dijawab menggunakan teori analisis wacana kritis dengan model Theo van Leeuwen. Model analisis Theo van Leeuwen ini umumnya digunakan untuk mengkaji atau menganalisis terkait bagaimana suatu peristiwa atau aktor digambarkan dalam pemberitaan, adakah aktor yang dikeluarkan dalam pemberitaan dan seperti apa strategi atau teknik yang digunakan untuk menggambarkan atau mengeluarkan suatu peristiwa dan aktor tersebut (Eriyanto, 2001). Model Theo van Leeuwen ini memiliki dua strategi atau teknik di dalamnya yaitu eksklusi dan inklusi. Eksklusi adalah strategi atau teknik yang digunakan untuk mengeluarkan aktor dalam sebuah pemberitaan (Eriyanto, 2001). Teknik eksklusi ini dibagi menjadi tiga cara yaitu pasivasi, nominalisasi, dan penggantian anak kalimat. Membuat kalimat dengan bentuk pasif adalah cara klasik untuk menghilangkan aktor dalam suatu wacana pemberitaan, bisa juga dilakukan dengan cara mengubah verba (kata kerja) menjadi nomina (kata benda), dan cara terakhir adalah dengan mengganti subjek menggunakan anak kalimat sehingga aktor dalam teks berita tidak muncul (Eriyanto, 2001).

Di samping itu, inklusi adalah strategi atau teknik yang digunakan untuk menggambarkan aktor dalam sebuah pemberitaan (Eriyanto, 2001). Teknik inklusi ini dibagi menjadi tujuh cara yaitu diferensiasi-indiferensiasi, objektivitas-abstarksi, nominasikategorisasi, nominasi-identifikasi, determinasi-indeterminasi, asimilasiindividualisasi, asosiasi-disosiasi. Cara pertama berkaitan dengan apakah aktor atau peristiwa lain yang lebih dominan atau bagus dihadirkan untuk menyudutkan aktor tertentu atau tidak. Lalu, bisa juga dengan menampilkan peristiwa atau aktor secara abstrak sehingga memberikan pemaknaan yang berbeda di khalayak umum atau ditampilkan secara konkret. Selain itu, bisa juga dengan memberikan kategori pada aktor yang ditampilkan dalam teks wacana berita atau ditampilkan apa adanya. Cara lain bisa dengan memberi anak kalimat untuk memperjelas teks berita atau tidak memberi penjelasan lain. Lalu, bisa pula dengan menyebutkan aktor atau peristiwa secara anonim untuk memberikan kesan yang berbeda jika dibaca khalayak umum atau disebutkan secara 
jelas. Selain itu, bisa juga menampilkan komunitas atau kelompok sosial dari aktor yang dituju atau menampilkan yang spesifik. Terakhir adalah dengan cara, perisitwa atau aktor dalam teks berita itu ditampilkan sendiri atau dihubungkan dengan yang lain.

Tujuan dari penelitian ini adalah memaparkan tentang ada atau tidaknya teknik yang digunakan koran digital untuk mengeluarkan dan menggambarkan aktor atau peristiwa terkait pemberitaan perundungan terhadap pasangan gay Thailand. Selain itu, memaparkan teknik yang digunakan koran digital dalam mengeluarkan aktor atau peristiwa terkait pemberitaan perundungan terhadap pasangan gay Thailand. Serta, memaparkan teknik yang digunakan koran digital dalam menggambarkan aktor atau peristiwa tersebut.

Penelitian tentang penggambaran aktor dalam sebuah berita sebelumnya sudah pernah diteliti oleh Sobari, T., Abdurrokhman, D., dan Sadiah, L. dengan judul penelitian Analisis Eksklusi dan Inklusi Pada Berita Pembebasan Lahan Kulon Progo Berdasarkan Model Theo Van Leeuwen yang terdapat dalam Jurnal Parole Vol. 1, No. 01, Januari 2018. Hasil dari penelitian tersebut menunjukkan bahwa, teks wacana berita 1 (Tribunnews.com) memarjinalkan para relawan aktivis solidaritas dengan menggunakan teknik eksklusi pasivasi dan nominalisasi serta teknik inklusi diferensia-indeferensia dan nominasikategorisasi. Selain itu, teks wacana berita 2 (Trito.id) memarjinalkan PT Angkasa Pura 1 dengan menggunakan teknik eksklusi pasivasi dan nominalisasi serta teknik inklusi diferensia-indeferensia. Penelitian lain juga pernah dilakukan oleh Putra, A. S., Hartanto, B. H., dan Rochmah, E. C. dengan judul Keberpihakan Penulisan Pelaku Kriminalitas dalam Surat Kabar Harian Pos Kota Edisi 1 Juli 2020 yang terdapat dalam Jurnal Stilistika Vol. 14, No. 1, Januari 2021. Hasil dari penelitian tersebut menunjukkan bahwa wartawan surat kabar harian Pos Kota masih berpihak pada pelaku dalam pemberitaan terkait kriminalitas.

Perbedaan penelitian ini dengan penelitian sebelumnya adalah pada objek yang diteliti. Penelitian ini menggunakan berbagai berita atau koran-koran digital yang memberitakan terkait perundungan yang dilakukan oleh sejumlah warganet Indonesia terhadap pasangan gay Thailand sebagai objek yang diteliti, sedangkan yang sebelumnya meneliti berita pembebasan lahan Kulon Progo dan pemberitaan tentang kriminalitas pada surat kabar harian Pos Kota. Persamaannya adalah sama-sama meneliti suatu berita dan melihat teknik-teknik yang digunakan penulis dalam menulis sebuah berita.

\section{METODE}

Penelitian ini menggunakan metode kualitatif dengan deskriptif. Menurut Sugiyono (2017), metode kualitatif adalah metode yang digunakan oleh peneliti untuk mengkaji suatu objek pada kondisi alamiah di mana peneliti berperan sebagai instrumen kunci. Metode ini digunakan karena penelitian ini berusaha menggambarkan pemberitaan terhadap suatu kasus di media-media online. Teknik yang digunakan untuk pengumpulan data adalah teknik dokumen berupa tulisan atau berita di media online terkait catatan peristiwa perundungan terhadap pasangan gay Thailand (Sugiyono, 2017) dan teknik catat dengan mencatat tulisan-tulisan 
yang mendukung penelitian (Mahsun, 2012). Teknik analisis datanya adalah dengan mereduksi data yaitu memilih data yang berkaitan dengan pemberitaan online terkait perundungan terhadap pasangan gay Thailand, lalu menyajikan data dalam tabel sesuai dengan model yang dirujuk, serta penarikan kesimpulan (Sugiyono, 2017).

\section{HASIL DAN PEMBAHASAN}

Setelah dilakukan pengumpulan data dan memilih data yang berkaitan dengan objek penelitian yaitu lima (5) koran digital yang terbit tanggal 13 April 2021 yaitu detik.com, brito.id, kompas.com, suara.com, makassar.terkini.id yang memberitakan terkait perundungan pasangan gay Thailand oleh sejumlah warganet Indonesia. Hasilnya adalah sebagai berikut.

Tabel 1. Penggambaran Aktor dalam Koran Digital Indonesia

\begin{tabular}{|c|c|c|c|c|c|c|c|c|c|c|c|}
\hline \multirow{2}{*}{ No } & \multirow{2}{*}{ Judul Berita } & \multicolumn{3}{|c|}{$\begin{array}{c}\text { Teknik } \\
\text { Eksklusi }\end{array}$} & \multicolumn{7}{|c|}{$\begin{array}{l}\text { Teknik } \\
\text { Inklusi }\end{array}$} \\
\hline & & $\mathrm{P}$ & $\mathrm{N}$ & PAK & DI1 & OA & NK & NI & DI2 & AI & $\mathrm{AD}$ \\
\hline 1. & $\begin{array}{l}\text { Pernikahan Gay Thailand Dihujat } \\
\text { Netizen Indonesia, Ini Kata Sang } \\
\text { Pengantin }\end{array}$ & $\checkmark$ & $\checkmark$ & & $\checkmark$ & $\checkmark$ & & & $\checkmark$ & $\checkmark$ & \\
\hline 2. & $\begin{array}{l}\text { GANAS! Netizen Indonesia Bully } \\
\text { Pasangan Gay Thailand: Mengapa } \\
\text { Kalian Sangat Kasar pada Kami? }\end{array}$ & $\checkmark$ & & & & $\checkmark$ & $\checkmark$ & & $\checkmark$ & $\checkmark$ & $\checkmark$ \\
\hline 3. & $\begin{array}{l}\text { Pasangan Gay Thailand Ini Menikah, } \\
\text { Dapat Ancaman Mati Netizen Indonesia }\end{array}$ & $\checkmark$ & & & & & & $\checkmark$ & $\checkmark$ & $\checkmark$ & \\
\hline 4. & $\begin{array}{l}\text { Sempat Dihujat Netizen Indonesia, } \\
\text { Pasangan Gay Thailand Akhirnya Buka } \\
\text { Suara }\end{array}$ & & $\checkmark$ & & & $\checkmark$ & $\checkmark$ & & & & \\
\hline 5. & $\begin{array}{l}\text { Dihujat Netizen Indonesia, Pasangan } \\
\text { Gay Thailand: Agama Tidak } \\
\text { Mengajarimu Membenci }\end{array}$ & $\checkmark$ & & & & $\checkmark$ & & & & & \\
\hline
\end{tabular}

Keterangan:

$\mathrm{P} \quad$ : Pasivasi

$\mathrm{N} \quad$ : Nominalisasi

PAK : Penggantian Anak Kalimat

DI1 : Diferensiasi-Indiferensiasi

OA : Objektivitas-Abstraksi

Berdasarkan tabel di atas, peneliti menemukan teknik eksklusi berupa pasivasi terdapat dalam empat (4) teks wacana berita dan nominasi terdapat dalam dua (2) teks wacana berita. Selain itu, teknik inklusi berupa diferensiasi-indifernsiasi terdapat dalam satu (1) teks wacana berita, objektivitas-abstraksi terdapat dalam
NK : Nominasi-Kategorisasi

NI : Nominasi-Identifikasi

DI2 : Determinasi-Indeterminasi

AI : Asimilasi-Individualisasi

AD : Asosiasi-Disosiasi

empat (4) teks wacana berita, nominasikategorisasi terdapat dalam dua (2) teks wacana berita, nominasi-identifikasi terdapat dalam satu (1) teks wacana berita, determinasi-indeterminasi terdapat dalam tiga (3) teks wacana berita, asimilasi-individualisasi terdapat dalam tiga (3) teks wacana berita, dan asosiasi-disosiasi terdapat 
dalam satu (1) teks wacana berita. Pembahasannya adalah sebagai berikut.

\section{Teknik Eksklusi \\ Pasivasi}

Teknik eksklusi berupa pasivasi terdapat dalam teks wacana berita yang berjudul "Pernikahan Gay Thailand Dihujat Netizen Indonesia, Ini Kata Sang Pengantin", yaitu pada kutipan teks berikut.

Semua orang yang saya sebutkan di atas, diancam SEMUA ... bf saya, orang tua, kerabat termasuk fotografer!! ... (1P)

Kutipan teks tersebut termasuk ke dalam teknik pasivasi karena kutipan tersebut berbentuk kalimat pasif dengan menggunakan kata "diancam". Dengan demikian, aktor atau pelaku yang "mengancam" bf, orang tua, kerabat dan fotografer dari korban tidak muncul dalam kutipan tersebut.

Teknik eksklusi berupa pasivasi terdapat dalam teks wacana berita yang berjudul "GANAS! Netizen Indonesia Bully Pasangan Gay Thailand: Mengapa Kalian Sangat Kasar pada Kami?", yaitu pada kutipan teks berikut.

Setelah mendapat ancaman bertubi-tubi, Suria dan kekasihnya merasa jengah dan juga terganggu. (2P)

Kutipan teks tersebut termasuk ke dalam teknik pasivasi karena kutipan tersebut berbentuk kalimat pasif dengan menggunakan kata "terganggu". Dengan demikian, aktor atau pelaku yang "mengganggu" Suria dan kekasihnya tidak muncul dalam kutipan tersebut.
Teknik eksklusi berupa pasivasi terdapat dalam teks wacana berita yang berjudul "Pasangan Gay Thailand Ini Menikah, Dapat Ancaman Mati Netizen Indonesia", yaitu pada kutipan teks berikut.

Tak berhenti sampai di situ, netizen Indonesia dilaporkan juga melontarkan hinaan mulai dari sialan maupun orang gila. (3P)

Kutipan teks tersebut termasuk ke dalam teknik pasivasi karena kutipan tersebut berbentuk kalimat pasif dengan menggunakan kata "dilaporkan". Dengan demikian, aktor yang "melaporkan" hinaan dari netizen Indonesia tidak muncul dalam kutipan tersebut.

Teknik eksklusi berupa pasivasi terdapat dalam teks wacana berita yang berjudul "Dihujat Netizen Indonesia, Pasangan Gay Thailand: Agama Tidak Mengajarimu Membenci”, yaitu pada kutipan teks berikut.

Namun, ia memutuskan angkat bicara lantaran tak tahan lagi dihujat selama tiga hari sejak pernikahan mereka berlangsung. (5P)

Kutipan teks tersebut termasuk ke dalam teknik pasivasi karena kutipan tersebut berbentuk kalimat pasif dengan menggunakan kata "dihujat". Dengan demikian, aktor yang "menghujat" pasangan gay tersebut tidak muncul dalam kutipan tersebut.

\section{Nominalisasi}

Teknik eksklusi berupa nominalisasi terdapat dalam teks wacana berita yang berjudul "Pernikahan Gay Thailand Dihujat Netizen Indonesia, Ini Kata Sang 
Pengantin", yaitu pada kutipan teks berikut.

Pernikahan sesama jenis asal Thailand jadi viral. (1N)

Kutipan teks tersebut termasuk ke dalam teknik nominalisasi karena pada kutipan tersebut terjadi proses perubahan kata, dari kata kerja yaitu "menikah" menjadi kata benda atau nomina yaitu "pernikahan". Dengan demikian, aktor yang melakukan pernikahan tidak muncul.

Teknik eksklusi berupa nominalisasi terdapat dalam teks wacana berita yang berjudul "Sempat Dihujat Netizen Indonesia, Pasangan Gay Thailand Akhirnya Buka Suara", yaitu pada kutipan teks berikut.

Foto pernikahan pasangan gay asal Thailand tengah ramai menjadi pembicaraan di jagat maya. $(4 \mathrm{~N})$

Kutipan teks tersebut termasuk ke dalam teknik nominalisasi karena pada kutipan tersebut terjadi proses perubahan kata, dari kata kerja yaitu "membicarakan" menjadi kata benda atau nomina yaitu "pembicaraan". Dengan demikian, aktor yang melakukan pembicaraan terkait foto pernikahan gay asal Thailand tidak muncul.

\section{Teknik Inklusi \\ Diferensiasi-Indiferensiasi}

Teknik inklusi berupa diferensiasiindiferensiasi terdapat dalam teks wacana berita yang berjudul "Pernikahan Gay Thailand Dihujat Netizen Indonesia, Ini Kata Sang Pengantin", yaitu pada kutipan teks berikut.
Pasangan bernama Bas dan Smile itu menikah dengan mendapatkan restu dari keluarga. Namun, netizen Indonesia ramai-ramai menghujat Facebook pasangan tersebut.

Masyarakat Thailand umumnya menerima komunitas LGBTQ. (1DI1)

Kutipan teks tersebut termasuk ke dalam teknik Diferensiasi karena kutipan tersebut terdapat garis batas antara pihak pasangan gay dengan pihak netizen Indonesia. Di mana, dengan adanya kutipan "menikah dengan mendapatkan restu dari keluarga" dan "menerima komunitas LGBTQ" bisa membuat pembaca berpikir bahwa pasangan gay tersebut tidak perlu takut dan merasa bersalah karena pada dasarnya dari pihak keluarga maupun masyarakat di negara tempat mereka tinggal tidak mempermasalahkan hal tersebut. Sementara itu, netizen Indonesia dianggap buruk karena telah menghujat dan ikut campur terkait pasangan gay Thailand tersebut.

\section{Objektivitas-Abstraksi}

Teknik inklusi berupa objektivitasabstraksi terdapat dalam teks wacana berita yang berjudul "Pernikahan Gay Thailand Dihujat Netizen Indonesia, Ini Kata Sang Pengantin", yaitu pada kutipan teks berikut.

Banyak netizen Indonesia yang membahas soal agama yang menentang pernikahan mereka. (1OA)

Kutipan teks tersebut termasuk ke dalam teknik abstraksi karena pada kutipan tersebut menggunakan kata "banyak" untuk menggambarkan 
netizen Indonesia yang suka membahas agama yang menentang pernikahan gay. Dengan demikian, pembaca dapat menilai bahwa netizen Indonesia dipandang kurang terbuka pemikirannya, kebanyakan dari mereka suka membahas suatu peristiwa yang bertentangan dengan agamanya, padahal tidak semua orang memiliki agama yang sama.

Teknik inklusi berupa objektivitasabstraksi terdapat dalam teks wacana berita yang berjudul "GANAS! Netizen Indonesia Bully Pasangan Gay Thailand: Mengapa Kalian Sangat Kasar pada Kami?", yaitu pada kutipan teks berikut.

Bahkan beberapa warganet mengancam akan membunuh Suria dan kekasihnya. (2OA)

Kutipan teks tersebut termasuk ke dalam teknik abstraksi karena pada kutipan tersebut menggunakan kata "beberapa" untuk menggambarkan warganet yang mengancam membunuh pasangan gay tersebut. Dengan demikian, pembaca dapat menilai bahwa warganet Indonesia dipandang buruk, karena beberapa dari mereka ada yang sampai mengancam ingin membunuh Suria dan kekasihnya.

Teknik inklusi berupa objektivitasabstraksi terdapat dalam teks wacana berita yang berjudul "Sempat Dihujat Netizen Indonesia, Pasangan Gay Thailand Akhirnya Buka Suara", yaitu pada kutipan teks berikut.

Selain komentar yang menyebut mereka sebagai "penyebab kehancuran dunia", banyak pula yang meninggalkan komentar bernada menghina dan merendahkan. (4OA)
Kutipan teks tersebut termasuk ke dalam teknik abstraksi karena pada kutipan tersebut menggunakan kata "banyak" untuk menggambarkan warganet yang menghina dan merendahkan pasangan gay tersebut. Dengan demikian, pembaca dapat menilai bahwa netizen Indonesia dipandang buruk, karena banyak diantara mereka yang berkomentar dengan menghina dan merendahkan pasangan tersebut.

Teknik inklusi berupa objektivitasabstraksi terdapat dalam teks wacana berita yang berjudul "Dihujat Netizen Indonesia, Pasangan Gay Thailand: Agama Tidak Mengajarimu Membenci", yaitu pada kutipan teks berikut ini:

Pasalnya, menurut Suriya, banyak pasangan gay Thailand yang juga telah melangsungkan pernikahan. (5OA)

Kutipan teks tersebut termasuk ke dalam teknik abstraksi karena pada kutipan tersebut menggunakan kata "banyak" untuk menggambarkan jumlah pasangan gay yang sudah menikah. Dengan demikian, pembaca dapat menilai bahwa tidak ada masalah jika pasangan gay tersebut melangsungkan pernikahan di Thailand karena telah banyak yang melakukannya.

\section{Nominasi-Kategorisasi}

Teknik inklusi berupa nominasikategorisasi terdapat dalam teks wacana berita yang berjudul "GANAS! Netizen Indonesia Bully Pasangan Gay Thailand: Mengapa Kalian Sangat Kasar pada Kami?", yaitu pada kutipan teks berikut ini. 
Kedua 'pria gemulai' ini tiba-tiba media sosialnya didatangi warganet Indonesia yang menurutnya bersikap bar bar. $(2 \mathrm{NK})$

Kutipan teks tersebut termasuk ke dalam teknik kategorisasi karena pada kutipan tersebut aktor tidak disebutkan secara jelas, melainkan menggunakan frasa "pria gemulai" untuk menampilkan aktor yang media sosialnya didatangi warganet Indonesia. Dengan demikian, pembaca dapat mengasosiasikan "pria gemulai" yang menganggap warganet Indonesia itu bersikap bar-bar.

Teknik inklusi berupa nominasikategorisasi terdapat dalam teks wacana berita yang berjudul "Sempat Dihujat Netizen Indonesia, Pasangan Gay Thailand Akhirnya Buka Suara", yaitu pada kutipan teks berikut.

Meski begitu, unggahan Suriya Koedsang mendadak banjir komentar homofobia dari netizen Indonesia. (4NK)

Kutipan teks tersebut termasuk ke dalam teknik kategorisasi karena pada kutipan tersebut aktor tidak disebutkan secara jelas, melainkan menggunakan kata "homofobia" untuk menampilkan aktor yang membanjiri komentar unggahan Suriya. Dengan demikian, pembaca dapat mengasosiasikan "homofobia" itu yang kerap membanjiri komentar dari unggahan pasangan gay.

\section{Nominasi-Identifikasi}

Teknik inklusi berupa nominasiidentifikasi terdapat dalam teks wacana berita yang berjudul "Pasangan Gay Thailand Ini Menikah, Dapat Ancaman
Mati Netizen Indonesia", yaitu pada kutipan teks berikut ini:

Ronnarong menyatakan, setiap orang Indonesia yang sudah memberikan komentar negatif kepada pasangan gay itu dilarang ke Thailand. (3NI)

Kutipan teks tersebut termasuk ke dalam teknik identifikasi karena pada kutipan tersebut menggunakan anak kalimat "yang sudah memberikan komentar negatif kepada pasangan gay itu". Dengan demikian, orang Indonesia yang pernah berkomentar negatif kepada pasangan gay tersebut dilarang masuk Thailand.

\section{Determinasi-Indeterminasi}

Teknik inklusi berupa determinasiindeterminasi terdapat dalam teks wacana berita yang berjudul "Pernikahan Gay Thailand Dihujat Netizen Indonesia, Ini Kata Sang Pengantin", yaitu pada kutipan teks berikut.

Pasangan bernama Bas dan Smile itu menikah dengan mendapatkan restu dari keluarga. (1DI2)

Kutipan teks tersebut termasuk ke dalam teknik indeterminasi karena pada kutipan tersebut aktor disebutkan secara jelas. Dengan demikian, pemberitaan tersebut secara jelas menampilkan aktor yang bermakna tunggal yaitu "Bas dan Smile" sebagai pasangan gay yang menikah.

Teknik inklusi berupa determinasiindeterminasi terdapat dalam teks wacana berita yang berjudul "GANAS! Netizen Indonesia Bully Pasangan Gay Thailand: Mengapa Kalian Sangat Kasar pada Kami?", yaitu pada kutipan teks berikut. 
Orang Indonesia kapan saja kalian masuk ke Thailand, saya akan meminta polisi menangkap kalian,' ancam Ronnarong. (2DI2)

Kutipan teks tersebut termasuk ke dalam teknik determinasi karena pada kutipan tersebut aktor tidak disebutkan secara jelas. Dengan demikian, pemberitaan tersebut tidak menampilkan aktor bermakna tunggal, tetapi jamak yaitu penggunaan "orang Indonesia" yang bermakna bahwa semua orang Indonesia jika masuk ke Thailand akan ditangkap polisi.

Teknik inklusi berupa determinasiindeterminasi terdapat dalam teks wacana berita yang berjudul "Pasangan Gay Thailand Ini Menikah, Dapat Ancaman Mati Netizen Indonesia", yaitu pada kutipan teks berikut.

Tak hanya itu, seorang pengacara asal Thailand yaitu Ronnarong Kaewpetch juga ikut angkat suara. (3DI2)

Kutipan teks tersebut termasuk ke dalam teknik indeterminasi karena pada kutipan tersebut aktor disebutkan secara jelas. Dengan demikian, pemberitaan tersebut secara jelas menampilkan aktor yang bermakna tunggal yaitu "Ronnarong Kaewpetch" sebagai pengacara yang menangani terkait pasangan gay tersebut.

\section{Asimilasi-Individualisasi}

Teknik inklusi berupa asimilasiindividualisasi terdapat dalam teks wacana berita yang berjudul "Pernikahan Gay Thailand Dihujat Netizen Indonesia, Ini Kata Sang Pengantin", yaitu pada kutipan teks berikut.
Bas dan Smile akhirnya buka suara di Facebooknya soal bully-an yang dilakukan netizen Indonesia terhadap mereka. (1AI)

Kutipan teks tersebut termasuk ke dalam teknik individualisasi karena pada kutipan tersebut kategori aktor yang dirundung disebutkan dengan jelas, tidak anonim. Aktor tersebut adalah Bas dan Smile yaitu korban perundungan yang dilakukan netizen Indonesia.

Teknik inklusi berupa asimilasiindividualisasi terdapat dalam teks wacana berita yang berjudul "GANAS! Netizen Indonesia Bully Pasangan Gay Thailand: Mengapa Kalian Sangat Kasar pada Kami?", yaitu pada kutipan teks berikut.

Hal itu yang baru-baru ini menimpa pasangan gay atau homoseksual asl Thailand Suriya dan kekasihnya. (2AI)

Kutipan teks tersebut termasuk ke dalam teknik individualisasi karena pada kutipan tersebut kategori aktor yang ditimpa oleh keganasan warganet Indonesia disebutkan dengan jelas, tidak anonim. Aktor tersebut adalah Suriya dan kekasihnya yaitu korban keganasan yang dilakukan warganet Indonesia.

Teknik inklusi berupa asimilasiindividualisasi terdapat dalam teks wacana berita yang berjudul "Pasangan Gay Thailand Ini Menikah, Dapat Ancaman Mati Netizen Indonesia", yaitu pada kutipan teks berikut.

Pasangan gay asal Thailand ini tak menyangka, momen bahagia pernikahan bakal membuat mereka berada dalam ketakutan. (3AI) 
Kutipan teks tersebut termasuk ke dalam teknik asimilasi karena pada kutipan tersebut aktor tidak disebutkan secara jelas. Dengan demikian, kesan yang timbul menjadi semua pasangan gay asal Thailand merasa berada dalam ketakutan di momen pernikahannya.

\section{Asosiasi-Disosiasi}

Teknik inklusi berupa asosiasidisosiasi terdapat dalam teks wacana berita yang berjudul "GANAS! Netizen Indonesia Bully Pasangan Gay Thailand: Mengapa Kalian Sangat Kasar pada Kami?", yaitu pada kutipan teks berikut.

Tetapi siapa sangka, warnet Indonesia langsung menyerbu unggahan itu untuk menumpahkan ejekan, hingga caci-maki."

"Bahkan perusahaan besar

Microsoft saja pernah menobatkan bahwa warganet RI menempati urutan terbawah warganet paling sopan se Asia Tenggara. (2AD)

Kutipan teks tersebut termasuk ke dalam teknik asosiasi karena pada kutipan tersebut penobatan yang dilakukan Microsoft kepada warganet RI diasosiasikan dengan kasus warganet RI yang mengejek dan mencaci-maki pasangan gay Thailand tersebut.

\section{PENUTUP}

Berdasarkan hasil dan pembahasan yang telah dipaparkan dapat di tarik kesimpulan bahwa, terdapat dua teknik yaitu eksklusi dan inklusi terkait pemberitaan perundungan terhadap pasangan gay Thailand pada lima (5) koran digital Indonesia yang terbit tanggal 13 April 2021. Teknik eksklusi berupa pasivasi ditemukan dalam empat (4) teks wacana berita, nominasi ditemukan dalam dua (2) teks wacana berita. Selain itu, teknik inklusi berupa diferensiasi-indifernsiasi ditemukan dalam satu (1) teks wacana berita, objektivitas-abstraksi ditemukan dalam empat (4) teks wacana berita, nominasikategorisasi ditemukan dalam dua (2) teks wacana berita, nominasiidentifikasi ditemukan dalam satu (1) teks wacana berita, determinasiindeterminasi ditemukan dalam tiga (3) teks wacana berita, asimilasiindividualisasi ditemukan dalam tiga (3) teks wacana berita, dan asosiasidisosiasi ditemukan dalam satu (1) teks wacana berita. Maka dari itu, teknik eksklusi tersebut digunakan oleh korankoran digital Indonesia untuk menghilangkan aktor yang merundung pasangan gay thailand dan teknik inklusi tersebut digunakan untuk menggambarkan dan menggeneralisasikan aktor dan peristiwa yang terdapat dalam perundungan pasangan gay Thailand.

Dengan demikian, peneliti berharap tulisan ini bisa digunakan sebagai referensi atau acuan bagi peneliti lain atau peneliti selanjutnya yang ingin mengkaji terkait analisis wacana dalam koran digital.

\section{DAFTAR PUSTAKA}

Chaer, A. (2012). Linguistik Umum. Jakarta: Rineka Cipta.

Djaman, F. (2021, April 13). Dihujat Netizen Indonesia, Pasangan Gay Thailand: Agama Tidak Mengajarimu Membenci. Retrieved April 30, 2021, from https://makassar.terkini.id/dihujat -netizen-indonesia-pasangan-gaythailand-agama-tidakmengajarimu-membenci/.

Eriyanto. (2001). Analisis Wacana 
Pengantar Analisis Teks Media. Yogyakarta: LKiS.

Kemp, S. (2021, 11 Februari). DIGITAL 2021: INDONESIA. Retrieved April 26, 2021, from https://datareportal.com/reports/di gital-2021-indonesia.

Kridalaksana, H. (2011). Kamus Linguistik Edisi Keempat. Jakarta: PT Gramedia Pustaka Utama.

Kushartanti, Yuwono, U., \& Launder, M. R. (2009). Pesona Bahasa: Langkah Awal Memahami Linguistik. Jakarta: PT Gramedia Pustaka Utama.

Mahsun. (2012). Metode Penelitian Bahasa: Tahapan Strategi, Metode, dan Tekniknya. Jakarta: Rajawali Pers.

Nariswari, A. \& Saraswati, A. (2021, April 13). Sempat Dihujat Netizen Indonesia, Pasangan Gay Thailand Akhirnya Buka Suara. Retrieved April 29, 2021, from https://www.suara.com/lifestyle/2 021/04/13/213109/sempatdihujat-netizen-indonesiapasangan-gay-thailand-akhirnyabuka-suara.

Oktaviani, K. (2021, April 13). Pernikahan Gay Thailand Dihujat Netizen Indonesia, Ini Kata Sang Pengantin. Retrieved April 29, 2021, from https://wolipop.detik.com/entertai nment-news/d5530813/pernikahan-gaythailand-dihujat-netizenindonesia-ini-kata-sang-pengantin
Putra, A. S., Hartanto, B. H., \& Rochmah, E. C. (2021). Keberpihakan Penulisan Pelaku Kriminalitas dalam Surat Kabar Harian Pos Kota Edisi 1 Juli 2020. Stilistika: Jurnal Pendidikan Bahasa Dan Sastra, 14(1), 22-31.

Sobari, T., Abdurrokhman, D., \& Sadiah, L. (2018). Analisis Eksklusi dan Inklusi Pada Berita Pembebasan Lahan Kulon Progo Berdasarkan Model Theo Van Leeuwen. Parole: Jurnal Pendidikan Bahasa Dan Sastra Indonesia, 1(1), 1-12.

Soeparno. (2013). Dasar-Dasar Linguistik Umum (Edisi Kedua). Tiara Wacana.

Sugiyono. (2017). MetodePenelitian Kuantitatif, Kualitatif dan $R \& D$. Bandung: PT Alfabet.

Utomo, A. P. (2021, April 13). Pasangan Gay Thailand Ini Menikah, Dapat Ancaman Mati Netizen Indonesia. Retrieved April 29, 2021, from https://www.kompas.com/global/r ead/2021/04/13/104655670/pasan gan-gay-thailand-ini-menikahdapat-ancaman-mati-netizenindonesia.

W, Ari. (2021, April 13). GANAS! Netizen Indonesia Bully Pasangan Gay Thailand: Mengapa Kalian Sangat Kasar pada Kami?. Retrieved April 29, 2021, from https://m.brito.id/ganas-netizenindonesia-bully-pasangan-gaythailand-mengapa-kalian-sangatkasar-pada-kami. 